University of Nebraska - Lincoln

DigitalCommons@University of Nebraska - Lincoln

US Army Research

U.S. Department of Defense

2010

Si implant-assisted Ohmic contacts to GaN

\author{
Cuong Nguyen \\ US Army Research Laboratory-SEDD, cuong.nguyen8@arl.army.mil \\ Pankaj Shah \\ US Army Research Laboratory-SEDD \\ Edward Leong \\ University of Maryland - College Park \\ Michael Derenge \\ US Army Research Laboratory-SEDD \\ Kenneth Jones \\ US Army Research Laboratory-SEDD
}

Follow this and additional works at: https://digitalcommons.unl.edu/usarmyresearch

Part of the Operations Research, Systems Engineering and Industrial Engineering Commons

Nguyen, Cuong; Shah, Pankaj; Leong, Edward; Derenge, Michael; and Jones, Kenneth, "Si implant-assisted Ohmic contacts to GaN" (2010). US Army Research. 140.

https://digitalcommons.unl.edu/usarmyresearch/140

This Article is brought to you for free and open access by the U.S. Department of Defense at DigitalCommons@University of Nebraska - Lincoln. It has been accepted for inclusion in US Army Research by an authorized administrator of DigitalCommons@University of Nebraska - Lincoln. 


\title{
Si implant-assisted Ohmic contacts to GaN
}

\author{
Cuong Nguyen ${ }^{\mathrm{a}, \mathrm{b}, *}$, Pankaj Shah ${ }^{\mathrm{a}}$, Edward Leong ${ }^{\mathrm{a}, \mathrm{b}}$, Michael Derenge ${ }^{\mathrm{a}}$, Kenneth Jones ${ }^{\mathrm{a}}$ \\ ${ }^{a}$ US Army Research Laboratory-SEDD, Adelphi 20783, United States \\ ${ }^{\mathrm{b}}$ Department of Electrical and Computer Engineering, University of Maryland, College Park 20742, Maryland, United States
}

\section{A R T I C L E I N F O}

Article history:

Available online 1 July 2010

The review of this paper was arranged by Prof. A. Zaslavsky

\section{Keywords:}

GaN

Ohmic contacts

Ion implantation

Annealing cap

\begin{abstract}
A B S T R A C T
The contact resistance, $\rho_{\mathrm{C}}$, was measured for the traditional $\mathrm{Ti} / \mathrm{Al} / \mathrm{Ni} / \mathrm{Au}$ Ohmic contact for samples implanted with Si to $>10^{20} \mathrm{~cm}^{-3}$ and annealed at $1100,1150,1200$, or $1250{ }^{\circ} \mathrm{C}$ for 2,5 or $10 \mathrm{~min}$ using an AlN annealing cap. These results are compared with those for samples annealed in the same way, but were not implanted. The as-grown samples were doped to $3.56 \times 10^{17}$ or $6.67 \times 10^{16} \mathrm{~cm}^{-3}$ or were unintentionally (UI) doped. In almost all cases, $\rho_{\mathrm{C}}$ for the implanted sample was lower, and a record low $\rho_{\mathrm{C}}=2.66 \times 10^{-8} \Omega \mathrm{cm}^{2}$ was achieved for the more heavily doped implanted sample annealed at $1200{ }^{\circ} \mathrm{C}$ for $10 \mathrm{~min} . \rho_{\mathrm{C}}$ decreased with the doping concentration, and for the UI samples, Ohmic contacts could be made only if the samples were implanted. The surface roughness was also measured, and it was found for an as-grown with an RMS roughness of $0.303 \mathrm{~nm}$, the roughness increased from 0.623 after an $1100{ }^{\circ} \mathrm{C}$ anneal to $3.197 \mathrm{~nm}$ after a $1250^{\circ} \mathrm{C}$ anneal for the implanted samples annealed for $10 \mathrm{~min}$, and it increased from $1.280 \mathrm{~nm}$ to $5.357 \mathrm{~nm}$ under the same conditions for the samples that were not implanted.
\end{abstract}

Published by Elsevier Ltd.

\section{Introduction}

Reliable, low contact resistance, $\rho_{\mathrm{C}}$, Ohmic contacts to $n$-GaN can improve the operating characteristics of devices such as Schottky diodes and high power, high frequency, high electron, mobility transistors (HEMTs). For the high power HEMTs $\rho_{\mathrm{C}}$, can contribute significantly to the on-resistance, and for the high frequency HEMTs it contribute significantly to the channel resistance; in some cases its contribution can be as high as $50 \%$.

One reason $\rho_{\mathrm{C}}$ for these devices is relatively high is because the contacts are made to relatively low doped material. For Schottky diodes used in high power applications, the $n$-GaN is low doped to increase the breakdown voltage, while for the HEMTs, the contacts are made to unintentionally (UI) doped GaN or AlGaN. One can increase the local doping concentration where the contacts are made by selective area diffusion [1] or ion implantation [29]. The problem with ion implantation is that the GaN has to be annealed at temperatures above which the rate of the preferential evaporation [10] becomes significant, which creates hexagonal etch pits. Researchers have attempted to deal with this problem by annealing for a short time (30 s) in flowing $\mathrm{NH}_{3}$ [6,7], placing the samples face-to-face [2,3], under high $\mathrm{N}_{2}$ pressures [4,5], or with sputtered $\mathrm{Si}_{3} \mathrm{~N}_{4}[8,9]$ or AlN [4,5]. However, face-to-face capping does not hermetically seal the surface, the partial pressure of

\footnotetext{
* Corresponding author at: US Army Research Laboratory-SEDD, Adelphi 20783, United States. Tel.: +1 3013941421.

E-mail address: cuong.nguyen8@arl.army.mil (C. Nguyen).
}

$\mathrm{N}_{2}$ greatly exceeds the $\mathrm{N}_{2}$ over pressures that were used [10], and sputtered $\mathrm{Si}_{3} \mathrm{~N}_{4}$ [11] or AlN [12] does not stick very well and is relatively weak so it can be punctured by the large $\mathrm{N}_{2}$ vapor pressures at the annealing temperatures that were used.

We have developed an annealing cap composed of a thin ( $\sim 80 \mathrm{~nm}$ ) low temperature $\left(\sim 600^{\circ} \mathrm{C}\right.$ ) deposited AlN adhesion layer grown by metal organic chemical vapor deposition (MOCVD) and a thick $(\sim 1 \mu \mathrm{m})$ sputtered AlN layer for added strength [12] that can withstand annealing temperatures up to $\sim 1250^{\circ} \mathrm{C}$, which is about the temperature where the yield strength of AlN [13] is equal to the partial pressure of $\mathrm{N}_{2}$ in equilibrium with GaN. As a result we are able to study the effects of annealing for temperatures up to $1250{ }^{\circ} \mathrm{C}$ for various amounts of time on the contact resistance. In this paper we study the effects of annealing both samples that were implanted and were not implanted over the range of temperatures from 1100 to $1250{ }^{\circ} \mathrm{C}$ for 2,5 or $10 \mathrm{~min}$. We also examine how annealing affects the surface roughness of the GaN by measuring the RMS roughness using an atomic force microscope (AFM).

\section{Experimental procedure}

Three $2 \mu \mathrm{m}$ thick GaN films were grown at $1100{ }^{\circ} \mathrm{C}$ on sapphire substrates by MOCVD using a low temperature $\left(600^{\circ} \mathrm{C}\right) \mathrm{GaN}$ buffer layer. They were unintentionally doped or doped with $\mathrm{Si}$ using a $\mathrm{SiH}_{4}$ flow of 1 or $0.25 \mathrm{sccm}$ during the growth of the GaN films. A gold mask was used to create TLM patterns on one half of each of the wafers and totally covered the other half. Si was implanted through the opening where the contact pads were deposited later 
with doses of $1.5 \times 10^{15} \mathrm{~cm}^{-2}$ at 30 and $60 \mathrm{keV} \mathrm{[5].} \mathrm{The} \mathrm{peak} \mathrm{con-}$ centration obtained from a TRIM profile was $5.6 \times 10^{20} \mathrm{~cm}^{-3}$ at the depth of $21 \mathrm{~nm}$ and was below $10^{20} \mathrm{~cm}^{-3}$ for depths $>100 \mathrm{~nm}$. After removing the implant mask, $8 \times 10 \mathrm{~mm}$ samples were cut from the wafers, and an $80 \mathrm{~nm}$ MOCVD AlN film was deposited on them at $600{ }^{\circ} \mathrm{C}$ followed by the sputter deposition at $500{ }^{\circ} \mathrm{C}$ of a $1 \mu \mathrm{m}$ thick AlN film. One implanted sample was paired with one that was not, and they were annealed together under a nitrogen pressure at $1100,1150,1200$, or $1250^{\circ} \mathrm{C}$ for 2,5 or $10 \mathrm{~min}$. Following the annealing process, the AlN annealing cap was removed by a warm $\mathrm{KOH}$ solution. Then, the annealed samples were examined in an a scanning electron microscope (SEM) to investigate the morphology of the GaN surface to see if there had been any local hexagonal etch pits created by the preferential evaporation of the $\mathrm{N}$, and to also examine the effects of diffusion on the surface. Next, AFM scanning was used for measuring the RMS roughness of GaN after annealing. The RMS roughness was recorded over $5 \times 5$ or $25 \times 25 \mu^{2}$ areas on samples that were annealed at 1100,1150 , 1200 or $1250{ }^{\circ} \mathrm{C}$ for $10 \mathrm{~min}$.

Before the capping layers were deposited, $8 \times 10 \mathrm{~mm}$ samples were cut from each wafer for Hall effect and TLM measurements to electrically characterize the as-grown material. Ohmic contacts were fabricated using an alloyed metal stack of $\mathrm{Ti} / \mathrm{Al} / \mathrm{Ni} / \mathrm{Au}$ for the contact [14] with thicknesses of $10 / 100 / 50 / 20 \mathrm{~nm}$ followed by a $30 \mathrm{~s}$ rapid thermal anneal (RTA) at $800{ }^{\circ} \mathrm{C}$ under nitrogen pressure. Hall effect measurements were made to measure the carrier concentration, mobility, and sheet resistance of the initial GaN. To create the TLM patterns, a $\mathrm{Cr} / \mathrm{Ni}(30 / 200 \mathrm{~nm})$ bi-layer mask was used to form the mesas for the individual TLM structures using an RIE etch, the Ohmic metal pads were deposited over the implanted regions, and then the contacts were annealed. Both $\rho_{\mathrm{C}}$ and the sheet resistance, $R_{\mathrm{SH}}$ were determined from the $I-V$ measurements. TLM measurements were performed on an as-grown sample from each

Table 1

Hall effect measurements.

\begin{tabular}{llll}
\hline $\begin{array}{l}\text { Doping level } \\
\left(\mathrm{cm}^{-3}\right)\end{array}$ & $\begin{array}{l}\text { Mobility } \\
\left(\mathrm{cm}^{2} / \mathrm{V} \mathrm{s}\right)\end{array}$ & $\begin{array}{l}\text { Sheet resistance } \\
(\Omega / \mathrm{sq})\end{array}$ & $\begin{array}{l}\text { Specific contact } \\
\text { resistance }\left(\Omega \mathrm{cm}^{2}\right)\end{array}$ \\
\hline $3.56 \times 10^{17}$ & 417 & $3.46 \times 10^{2}$ & $3.90 \times 10^{-6}$ \\
$6.67 \times 10^{16}$ & 524 & $1.34 \times 10^{3}$ & $3.96 \times 10^{-5}$ \\
$\begin{array}{c}\text { Unintentionally } \\
\text { doped }\end{array}$ & $\begin{array}{l}\text { Unable to } \\
\text { measure }\end{array}$ & $8.4 \times 10^{4 \mathrm{a}}$ & $\begin{array}{l}\text { Unable to } \\
\text { measure }\end{array}$ \\
\hline
\end{tabular}

a Average sheet resistance from TLM measurements of the sheet resistance between the pads.
Table 2

Specific contact resistance of higher and lower doped samples.

\begin{tabular}{|c|c|c|c|c|c|}
\hline \multirow{2}{*}{$\begin{array}{l}T_{\text {Anneal }} \\
\left({ }^{\circ} \mathrm{C}\right)\end{array}$} & \multirow{2}{*}{$\begin{array}{l}\text { Time } \\
(\mathrm{min})\end{array}$} & \multicolumn{2}{|c|}{ Higher doped wafer } & \multicolumn{2}{|c|}{ Lower doped wafer } \\
\hline & & $\begin{array}{l}\rho_{\mathrm{C}}\left(\Omega \mathrm{cm}^{2}\right) \\
\text { Not- } \\
\text { implanted }\end{array}$ & $\begin{array}{l}\rho_{\mathrm{C}}\left(\Omega \mathrm{cm}^{2}\right) \\
\text { Implanted }\end{array}$ & $\begin{array}{l}\rho_{\mathrm{C}}\left(\Omega \mathrm{cm}^{2}\right) \\
\text { Not- } \\
\text { implanted }\end{array}$ & $\begin{array}{l}\rho_{\mathrm{C}}\left(\Omega \mathrm{cm}^{2}\right) \\
\text { Implanted }\end{array}$ \\
\hline 1100 & $\begin{array}{l}2 \\
5 \\
10\end{array}$ & $\begin{array}{l}7.87 \times 10^{-6} \\
5.50 \times 10^{-6} \\
7.87 \times 10^{-6}\end{array}$ & $\begin{array}{l}1.12 \times 10^{-5} \\
7.28 \times 10^{-4} \\
1.19 \times 10^{-6}\end{array}$ & $\begin{array}{l}4.17 \times 10^{-5} \\
1.19 \times 10^{-5} \\
3.47 \times 10^{-5}\end{array}$ & $\begin{array}{l}4.15 \times 10^{-4} \\
1.62 \times 10^{-5} \\
7.11 \times 10^{-6}\end{array}$ \\
\hline 1150 & $\begin{array}{l}2 \\
5 \\
10\end{array}$ & $\begin{array}{l}1.12 \times 10^{-5} \\
1.43 \times 10^{-6} \\
4.20 \times 10^{-7}\end{array}$ & $\begin{array}{l}8.52 \times 10^{-7} \\
4.57 \times 10^{-7} \\
1.43 \times 10^{-7}\end{array}$ & $\begin{array}{l}5.75 \times 10^{-6} \\
2.01 \times 10^{-5} \\
1.54 \times 10^{-5}\end{array}$ & $\begin{array}{l}2.40 \times 10^{-5} \\
9.81 \times 10^{-6} \\
1.05 \times 10^{-5}\end{array}$ \\
\hline 1200 & $\begin{array}{l}2 \\
5 \\
10\end{array}$ & $\begin{array}{l}3.74 \times 10^{-7} \\
1.01 \times 10^{-6} \\
1.24 \times 10^{-5}\end{array}$ & $\begin{array}{l}3.25 \times 10^{-7} \\
6.24 \times 10^{-7} \\
2.66 \times 10^{-8}\end{array}$ & $\begin{array}{l}1.50 \times 10^{-5} \\
8.94 \times 10^{-5} \\
2.56 \times 10^{-3}\end{array}$ & $\begin{array}{l}4.23 \times 10^{-6} \\
5.56 \times 10^{-6} \\
1.16 \times 10^{-6}\end{array}$ \\
\hline 1250 & $\begin{array}{l}2 \\
5 \\
10\end{array}$ & $\begin{array}{l}7.25 \times 10^{-6} \\
2.56 \times 10^{-4} \\
5.16 \times 10^{-4}\end{array}$ & $\begin{array}{l}8.44 \times 10^{-7} \\
8.95 \times 10^{-7} \\
3.38 \times 10^{-6}\end{array}$ & $\begin{array}{l}6.04 \times 10^{-4} \\
3.54 \times 10^{-3} \\
1.44 \times 10^{-2}\end{array}$ & $\begin{array}{l}7.47 \times 10^{-6} \\
2.24 \times 10^{-5} \\
1.19 \times 10^{-5}\end{array}$ \\
\hline
\end{tabular}

of the three wafers, as well as on annealed samples that were implanted or not implanted.

\section{Results and discussion}

As shown in Table 1, Hall effect measurements show that the carrier concentration for the film doped with a $1 \mathrm{sccm}$ flow of dilute $\mathrm{SiH}_{4}$ is $3.56 \times 10^{17} \mathrm{~cm}^{-3}$, and it is $6.67 \times 10^{16} \mathrm{~cm}^{-3}$ when the flow rate is $0.25 \mathrm{sccm}$. The corresponding mobilities are 417 and $524 \mathrm{~cm}^{2} / \mathrm{V} \mathrm{s}$, which is about what is expected for GaN films containing dislocation concentrations in the low $10^{9} \mathrm{~cm}^{-2}$ [15], which is typical for our films. We were unable to form Ohmic contacts to the UI doped material. However, we can estimate its carrier concentration from $R_{\mathrm{SH}}$ that was determined from our TLM measurements. It was $84,000 \Omega / \square$ compared to 346 and $1340 \Omega / \square$ for the doped samples suggesting the net carrier concentration in the UI doped sample was $\sim 10^{15} \mathrm{~cm}^{-3}$. We did not make Hall measurements on the annealed samples, but we noted that the average sheet resistance for the low doped sample was only $2.3 \%$ lower than it was for the sample that was not annealed, and it was only $1.8 \%$ lower for the higher doped sample. This suggests that processes that could profoundly affect the electrical properties, such as the formation of $\mathrm{N}$ vacancies through the preferential evaporation of $\mathrm{N}$, was held in check.
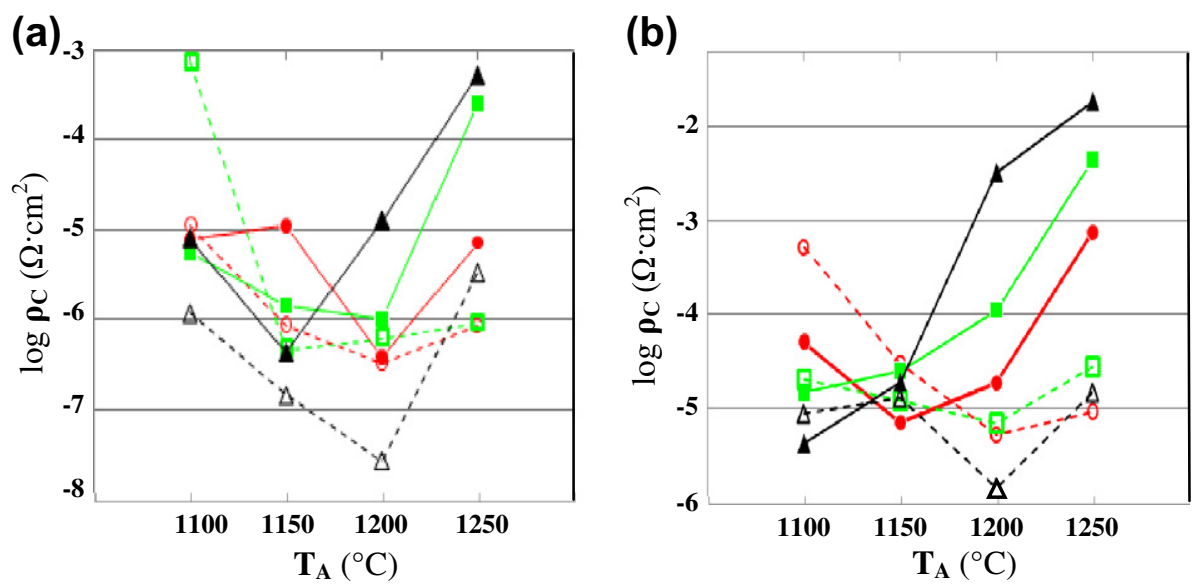

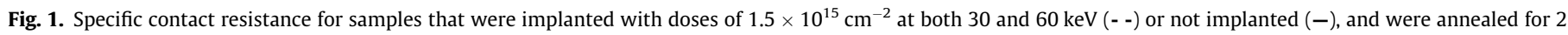
(๑), $5(\square)$, or $10(\Delta)$ min for the sample doped to the (a) heavier, and (b) lighter doped samples. 
Table 3

Specific contact resistance UI doped samples.

\begin{tabular}{|c|c|c|c|}
\hline \multirow[t]{2}{*}{$T_{\text {Anneal }}\left({ }^{\circ} \mathrm{C}\right)$} & \multirow[t]{2}{*}{ Time (min) } & \multicolumn{2}{|c|}{ Unintentionally doped } \\
\hline & & $\begin{array}{l}\rho_{\mathrm{C}}\left(\Omega \mathrm{cm}^{2}\right) \\
\text { Not-implanted }\end{array}$ & $\rho_{\mathrm{C}}\left(\Omega \mathrm{cm}^{2}\right)$ Implanted \\
\hline 1100 & $\begin{array}{l}2 \\
5 \\
10\end{array}$ & $\begin{array}{l}\text { Not Ohmic } \\
\text { Not Ohmic } \\
\text { Not Ohmic }\end{array}$ & $\begin{array}{l}\text { Not Ohmic } \\
1.47 \times 10^{-1} \\
9.13 \times 10^{-2}\end{array}$ \\
\hline 1150 & $\begin{array}{l}2 \\
5 \\
10\end{array}$ & $\begin{array}{l}\text { Not Ohmic } \\
\text { Not Ohmic } \\
\text { Not Ohmic }\end{array}$ & $\begin{array}{l}3.01 \times 10^{-1} \\
4.8 \times 10^{-1} \\
5.62 \times 10^{-2}\end{array}$ \\
\hline 1200 & $\begin{array}{l}2 \\
5 \\
10\end{array}$ & $\begin{array}{l}\text { Not Ohmic } \\
\text { Not Ohmic } \\
\text { Not Ohmic }\end{array}$ & $\begin{array}{l}2.08 \times 10^{-4} \\
1.08 \times 10^{-1} \\
3.0 \times 10^{-2}\end{array}$ \\
\hline 1250 & $\begin{array}{l}2 \\
5 \\
10\end{array}$ & $\begin{array}{l}\text { Not Ohmic } \\
\text { Not Ohmic } \\
\text { Not Ohmic }\end{array}$ & $\begin{array}{l}4.0 \times 10^{-2} \\
8.9 \times 10^{-4} \\
1.37 \times 10^{-2}\end{array}$ \\
\hline
\end{tabular}

The contact resistance to the more heavily doped sample was $3.90 \times 10^{-6} \Omega \mathrm{cm}^{2}$, which is similar to what others [14] have obtained. As seen in Fig. 1a and Table 2, annealing the implanted sample for a time, $t_{\mathrm{A}}=10 \mathrm{~min}$, has the most significant effect on reducing $\rho_{\mathrm{C}}$, and the largest reduction is achieved when the annealing temperature, $T_{\mathrm{A}}$, is $1200^{\circ} \mathrm{C}$, where we achieved a record low value for this carrier concentration of $2.66 \times 10^{-8} \Omega \mathrm{cm}^{2}$. The previous record was $3.6 \times 10^{-8} \Omega \mathrm{cm}^{2}$ [3] and most of the other values for implanted contacts were in the low $10^{-6}$ range. $\rho_{\mathrm{C}}$ decreases with $T_{\mathrm{A}}$ from 1150 to $1250{ }^{\circ} \mathrm{C}$ for all three values of $t_{\mathrm{A}}$, sug- gesting that increasing $T_{\mathrm{A}}$ and/or $t_{\mathrm{A}}$ increases the percent of the implants that have become electrically activated. For all three annealing times $\rho_{\mathrm{C}}$ is larger when $T_{\mathrm{A}}=1250{ }^{\circ} \mathrm{C}$ than it is at $1200{ }^{\circ} \mathrm{C}$, and the samples that were not implanted show the same behavior. It is also not likely this increase is due to the preferential evaporation of $\mathrm{N}$ because $\mathrm{N}$ vacancies are donors [16]. We will show that it is unlikely that much $\mathrm{N}$ escaped because our annealing cap remained intact. Rather, it seems likely this increase in $\rho_{\mathrm{C}}$ was due the effects of greater solid state diffusion at the higher $T_{\mathrm{A}}$.

At $3.96 \times 10^{-5} \Omega \mathrm{cm}^{2}, \rho_{\mathrm{C}}$ for the more lightly doped sample was $10 \mathrm{X}$ larger, but the implanted samples followed the same trends as those for the implanted more heavily doped sample. That is, $\rho_{\mathrm{C}}$ decreased with $T_{\mathrm{A}}$ up to $1200^{\circ} \mathrm{C}$, and then it increased for the $1250^{\circ} \mathrm{C}$ anneal. However, it was one to two orders of magnitude larger for comparably annealed samples. Again, the lowest $\rho_{\mathrm{C}}$ was achieved after the $10 \mathrm{~min}$ anneal at $1200^{\circ} \mathrm{C}$, with the value being $1.16 \times 10^{-6} \Omega \mathrm{cm}^{2}$. The trend is different for the samples that were annealed, but were not implanted; $\rho_{\mathrm{C}}$ essentially increased with both $T_{\mathrm{A}}$ and $t_{\mathrm{A}}$ with the exception of $1150^{\circ} \mathrm{C}$ annealing case. One possible explanation is that the annealing reduces the dislocation concentration, and it is more difficult to make a contact to a sample that has fewer dislocations that act as diffusion pipes. Although Ohmic contacts could not be made to the as-grown UI samples, they could be made to the implanted UI samples for all but the sample annealed for $2 \mathrm{~min}$ at $1100^{\circ} \mathrm{C}$, as is shown in Table 3 . The Ohmic contact could probably not be made because the implants had not been sufficiently activated. However, $\rho_{\mathrm{C}}$ is much larger than it is for the doped samples with values being in the $10^{-2}-10^{-1} \Omega \mathrm{cm}^{2}$ range with only the samples annealed at (a)

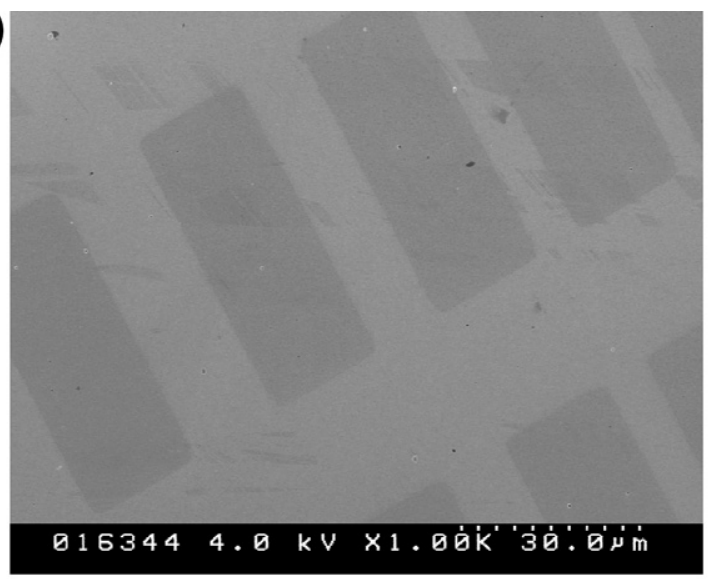

(c)

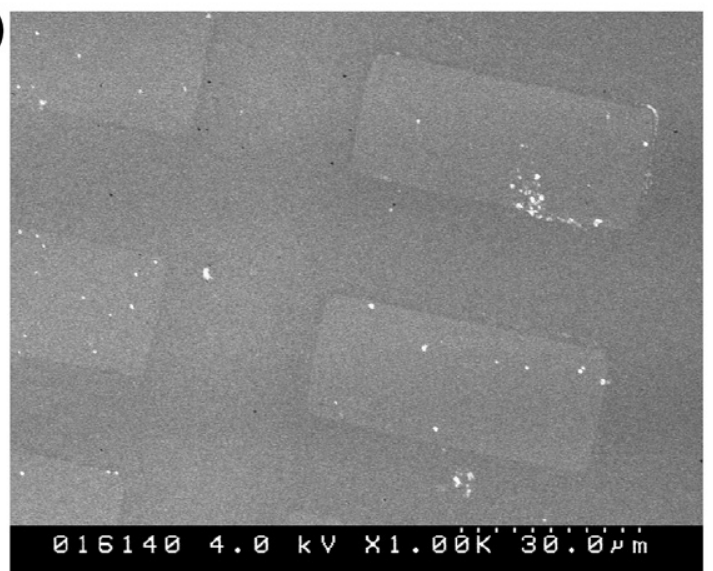

(b)

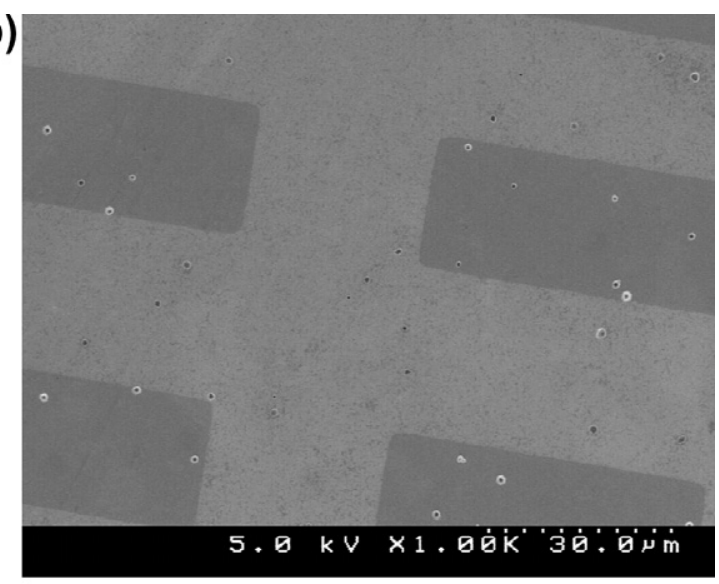

(d)

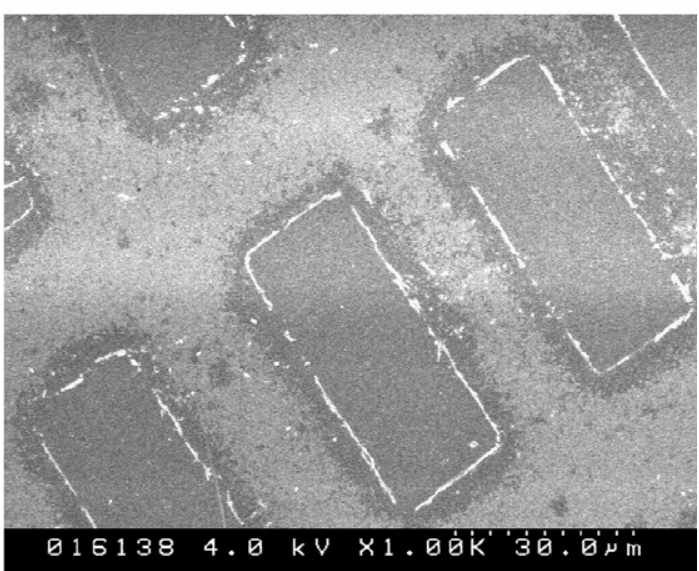

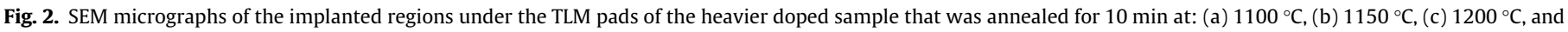
(d) $1250^{\circ} \mathrm{C}$. 
(a)

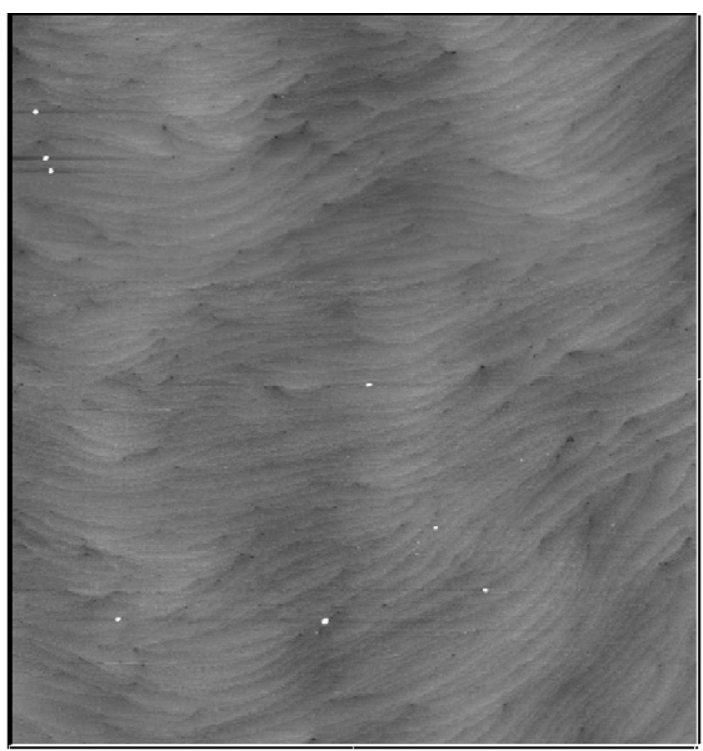

(b)

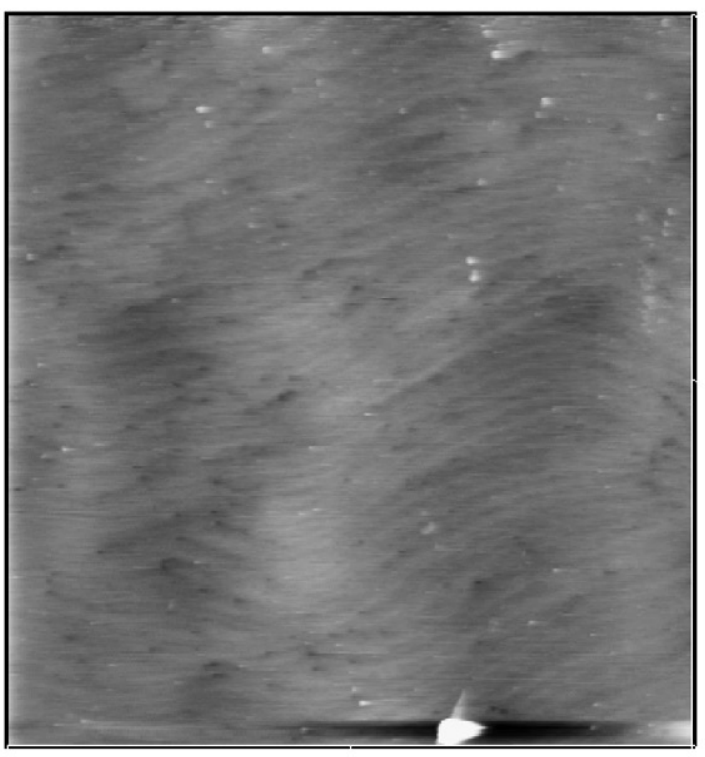

(d)

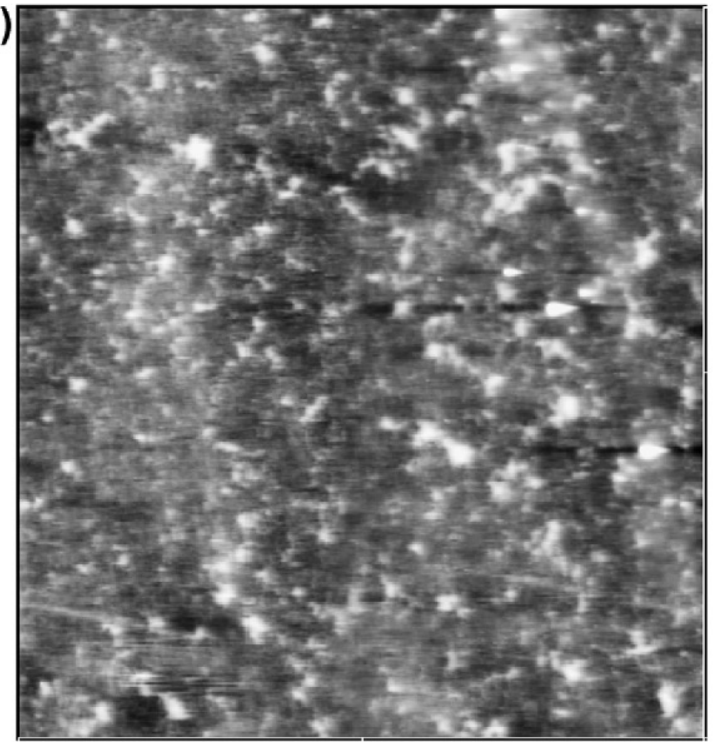

(c)

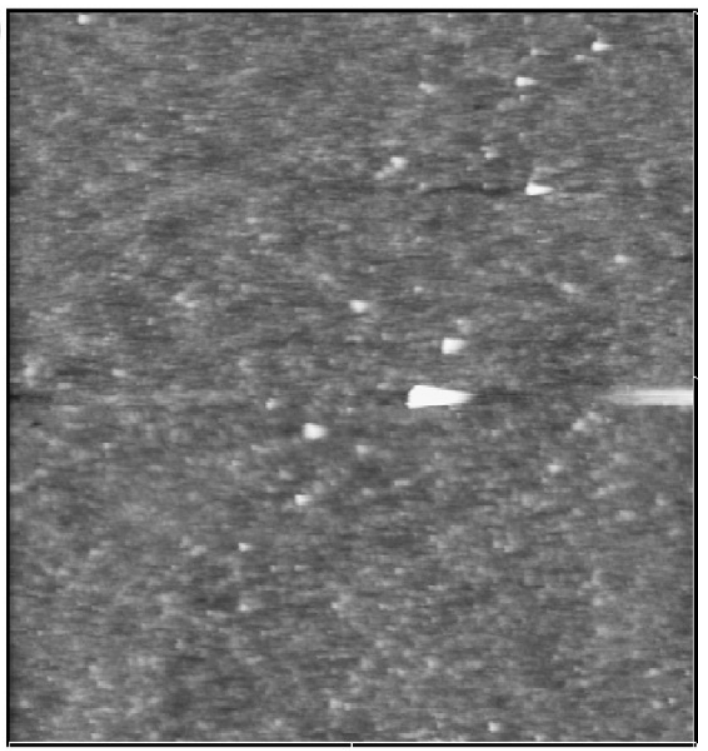

(e)

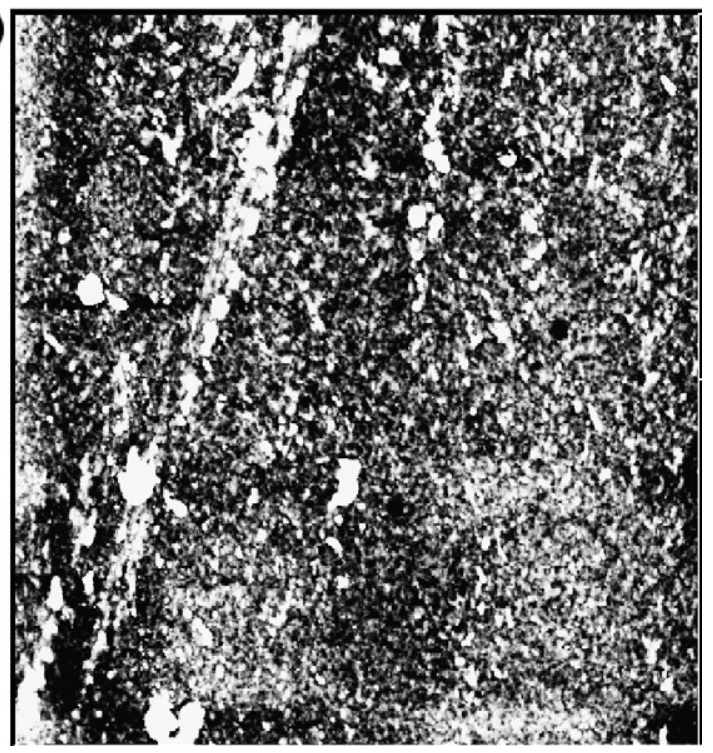

Fig. 3. AFM micrographs of the (a) as-grown sample, and for the implanted sample annealed for $10 \mathrm{~min}$ at, (b) $1100{ }^{\circ} \mathrm{C}$, (c) $1150^{\circ} \mathrm{C}$, (d) $1200{ }^{\circ} \mathrm{C}$, and (e) $1250{ }^{\circ} \mathrm{C}$. 
$1200^{\circ} \mathrm{C}$ for $2 \min \left(2.08 \times 10^{-4}\right)$ and $1250{ }^{\circ} \mathrm{C}$ for $5 \min \left(8.9 \times 10^{-4}\right)$ being in the $10^{-4} \Omega \mathrm{cm}^{2}$ range.

The SEM micrographs of the GaN surface with the AlN annealing cap etched off in Fig. 2 for the more heavily doped, implanted samples annealed for 10 min show that the annealing cap can withstand the stresses produced by the $\mathrm{N}_{2}$ vapor pressure, but the stress increases with $T_{\mathrm{A}}$. There are virtually no hexagonal etch pits typical of specimens annealed at these temperatures without a cap. However, as shown in the AFM micrographs in Fig. 3, the surfaces do become rougher as $T_{\mathrm{A}}$ increases. The RMS surface roughness increases from 0.623 , to 0.685 , to 1.086 , to $3.196 \mathrm{~nm}$ in a $5 \times 5 \mu \mathrm{m}^{2}$ area as $T_{\mathrm{A}}$ is increased from 1100 , to 1150 , to 1200 , to $1250{ }^{\circ} \mathrm{C}$. The RMS roughness for the as-grown sample was $0.303 \mathrm{~nm}$. For the comparable samples that were implanted, the RMS roughness was $1.280 \mathrm{~nm}$ for the sample annealed at $1100^{\circ} \mathrm{C}$, and it was 5.357 for the sample annealed at $1250{ }^{\circ} \mathrm{C}$. This information suggests that even though the $\mathrm{N}_{2}$ does not appear to be able to escape, the surface can be roughened by surface and/or solid state diffusion that can occur at these elevated temperatures.

\section{Conclusions}

When properly annealed, $\rho_{\mathrm{C}}$ for doped samples implanted with Si to $>10^{20} \mathrm{~cm}^{-3}$ near the surface can be reduced one to two orders of magnitude as compared to the doped samples that are not implanted, but annealed in the same way. $\rho_{\mathrm{C}}$ can also be reduced more than two orders of magnitude as compared to the as-grown film. We obtained a $\rho_{\mathrm{C}}=2.66 \times 10^{-8} \Omega \mathrm{cm}^{2}$ for a sample doped to $3.56 \times 10^{17} \mathrm{~cm}^{-3}$ and annealed for $10 \mathrm{~min}$ at $1200{ }^{\circ} \mathrm{C}$. For the asgrown sample, $\rho_{\mathrm{C}}=3.90 \times 10^{-6} \Omega \mathrm{cm}^{2}$. For the samples doped to $6.67 \times 10^{16} \mathrm{~cm}^{-3}, \rho_{\mathrm{C}}$ was $10-100$ times larger for the comparably annealed more lightly doped samples. Ohmic contacts could not be made to the UI samples, which we estimate to have a carrier concentration of $\sim 10^{15}$ from our sheet resistance measurements, and $\rho_{\mathrm{C}}$ was large $\left(\sim 10^{-2}-10^{-1} \Omega \mathrm{cm}^{2}\right)$ for the implanted samples.

For the more heavily doped samples $\rho_{\mathrm{C}}$ decreased with the annealing temperature, $T_{\mathrm{A}}$, from 1150 to $1250{ }^{\circ} \mathrm{C}$, but the decrease of $\rho_{\mathrm{C}}$ after the $1250^{\circ} \mathrm{C}$ anneal for the implanted samples is minimal, while $\rho_{\mathrm{C}}$ increased for the samples that were not implanted. It also tended to decrease with the annealing time, $t_{\mathrm{A}}$, for a given $T_{\mathrm{A}}$ for $t_{\mathrm{A}}=2,5$ or $10 \mathrm{~min}$ for the implanted samples, but tended to increase with $t_{\mathrm{A}}$ for the samples that were not implanted. For the more lightly doped samples the trends for $\rho_{\mathrm{C}}$ were similar to those for the more heavily doped samples for both the implanted samples and the samples that were not implanted. However, $\rho_{\mathrm{C}}$ tended to increase with $T_{\mathrm{A}}$, as well as $t_{\mathrm{A}}$. This could be due to the reduction in the dislocation concentration during the anneal, which would reduce the number of diffusion pipes for the Ohmic metal.

The changes in $\rho_{\mathrm{C}}$ are more likely to be due to diffusion in the bulk and on the surface, as opposed to the preferential evaporation of $\mathrm{N}$ because an AlN cap was used during the annealing process. The evidence that the cap was effective was the lack of hexagonal etch pits formed by the preferential evaporation of $\mathrm{N}$ when a cap is not used. In addition to changes in $\rho_{\mathrm{C}}$ evidence that there was considerable diffusion is reflected in the increase of the RMS surface roughness from 0.623 to $3.196 \mathrm{~nm}$ when $T_{\mathrm{A}}$ was increased from 1100 to $1250^{\circ} \mathrm{C}$ for the annealing time of $10 \mathrm{~min}$ for the more heavily doped sample that was implanted, and an increase from 1.280 to $5.357 \mathrm{~nm}$ over the same temperature range for the same time for the more heavily doped sample that was not implanted. The surface roughness of the as-grown sample was $0.303 \mathrm{~nm}$.

\section{References}

[1] Adivarahan V, Gaevski M, Koudymov A, Yang J, Simin G, Khan MA. IEEE Electron Dev Lett 2007;28:192-4.

[2] Pearton SJ, Vartuli CB, Zolper JC, Yuan C, Stall RA. Appl Phys Lett 1995;67:1435-7.

[3] Burm J, Chu K, Davis WA, Schaff WJ, Eastman LF. Appl Phys Lett 1997;70:464-6.

[4] Yu H, McCarthy L, Xing H, Shen L, Keller S, Denbaars SP, et al. Appl Phys Lett 2004;85:5254-6.

[5] Yu H, McCarthy L, Rajan S, Keller S, Denbaars S, Speck J, et al. IEEE Electron Dev Lett 2005;26:283-5.

[6] Recht F, McCarthy L, Rajan S, Chakraborty A, Poblenz C, Corrion A, et al. IEEE Electron Dev Lett 2006;27:205-7.

[7] Kocan M, Umana-Membeno GA, Chung JS, Recht F, McCarthy L, Keller S, et al. J Electron Mater 2007;36:1156-9.

[8] Nanjo T, Takeuchi M, Suita M, Oishi T, Tokuda Y, Aoyagi Y. Appl Phys Express 2008;1:011101-3.

[9] Shiino T, Saitoh T, Nakmura T, Inada T. J Nucl Instrum 2009;B267:1571-4.

[10] Karpinski J, Jun J, Porowski S. J Cryst Growth 1984;66:1-10.

[11] Matsunaga S, Yoshida S, Kawaji T, Inada T. J Appl Phys 2004;95:2461-6.

[12] Hager IV CE, Jones KA, Derenge MA, Zheleva TS. J Appl Phys 2009;105:033713-7.

[13] Yonenaga I, Motoki K. J Appl Phys 2001;90:6539-41.

[14] Lin ME, Ma Z, Huang FY, Fan ZF, Allen LH, Morkoc H. Appl Phys Lett 1994;66:1003-5.

[15] Look DC, Sizelove JR. Phys Rev Lett 1999;82:1237-40.

[16] Gotz W, Johnson NM, Chen C, Liu H, Kuo C, Imier W. Appl Phys Lett 1998;68:3144-6. 